\title{
East and West: Trust or Distrust?
}

\begin{abstract}
The return of Asia to the center stage of world history can be explained in part by its absorbing of the wisdom and ideas of Western civilization. But to stem the rising distrust between East and West, the West must now learn some critical lessons from China's Asian neighbors on how to manage the rise of China.
\end{abstract}

The world stands at one of its most important crossroads in human history. As we move inexorably away from the brief era of Western domination of human history, societies from the East and the West will have to find a new balance. And there are two clear paths that the East and West can take: toward convergence or divergence.

In theory, there should be divergence. Many Asian societies and civilizations still have strong memories of Western domination. At its peak, the West trampled on the Islamic world, effortlessly colonized India and humiliated China. As once downtrodden societies recover their civilizational strength and vigor, it would be perfectly natural to return with a desire to wreak vengeance on the West. As Samuel Huntington once famously predicted, the world should be experiencing a clash of civilizations.

Instead, the opposite has happened. Thanks to the generous gifts of Western wisdom, especially the gift of Western reasoning, there is a fundamental convergence taking place in the dreams and ambitions of young people in both East and West. As Larry Summers and I observed in our 2016 essay "The Fusion of Civilizations," "most people around the world now have the same aspirations as the Western middle classes: they want their children to get good educations, land good jobs, and live happy, productive lives as members of stable, peaceful communities. Instead of feeling depressed, the West should be celebrating its phenomenal success at injecting the key elements of its worldview into other great civilizations."

A few years later, Yuval Noah Harari reached the same conclusion when he observed in Sapiens that nearly all humans today share the same geopolitical, economic, legal, and scientific systems. As he argues, "today when Iran and the United States rattle swords at one another, they both speak the language of nation states, capitalist economies, international rights, and nuclear physics." There is no

Originally published in Edelman Trust Barometer, Jan 19, 2020 
better living proof of the possible psychological convergence between Iran and America than the foreign minister of Iran, Mohammad Javad Zarif. His deep knowledge and understanding of Western history and culture would put many great Western minds to shame.

Thanks to the spread of Western wisdom and the global convergence on norms such as the rule of law, the societies with the highest levels of trust in both government and business today are China, Indonesia, India, and the UAE, much higher than in many Western countries including the United States, United Kingdom, Germany and France.

The magical benefits of greater convergence between Eastern and Western minds can be seen in the most competitive human laboratory of the world. When young entrepreneurs flock to Silicon Valley in search of the next start-up and when young freshmen enroll in the greatest Ivy League universities, they are barely aware that they come from the East or the West. Instead, they speak a common language of aspirations and see no problem collaborating across cultures in search of achieving extraordinary excellence. Similarly, when Chinese university presidents strive to create the best universities in the world, they know that they have to emulate the best practices of American and European universities. In short, many forces are pushing the 7.5 billion people of the world toward greater convergence. All this should naturally lead to greater trust between the East and the West.

Yet, there are also equally strong forces pushing humanity toward divergence. One has already broken out: the geopolitical contest between the US and China. This will be a multidimensional contest, in economics and politics, in the military and cultural spheres. Kiron Skinner, the former director of policy planning in the State Department, astutely observed that this would be the first struggle that the US would have with a "non-Caucasian power." She put her finger on a key factor that would lead to distrust between the US and China.

This distrust explains how the forces of science and technology, which have been propelling humanity toward a common understanding of our natural world and which have built bridges across cultures, can now become a divisive force. If a German or French (or even Japanese or Indian) telecommunications company had been the leader in developing 5G technology, the US would have acquiesced. However, when a Chinese company, Huawei, became the technological leader, the US balked and decided to throttle Huawei. As Tom Friedman presciently observed, "However much justified, this move was the equivalent of China freezing out Apple and Microsoft. It was an earthquake in China's tech lands... Lots of Chinese tech companies are now thinking: We will never, ever, ever leave ourselves again in a situation where we are totally dependent on America for key components. Time to double down on making our own."

The struggle over Huawei is only the tip of a massive iceberg. The US will make a major effort to "decouple" itself from Chinese technology, perhaps in the hope that this will stall China's development. It could. But it would be unwise to bet on it. As Asia's leading historian Professor Wang Gungwu has wisely observed, China is the only major civilization that has fallen down four times and stood up again each time. 
Right now, it has only just begun to revitalize its civilizational sinews. The return of China is unstoppable.

Having defeated the mighty Soviet Union without firing a shot, it would be perfectly natural for American strategic planners to believe that America will prevail again. And it well could. However, the world of 2020 is vastly different from the world of 1950 when the Cold War began. All around the world, strong and selfconfident societies are emerging. The 6 billion people of the world who live outside the US and China will not be easily dragooned to join one side or another. They will make their own choices.

America and the West could well learn some valuable lessons from how China's Asian neighbors manage the rise of China. Many of these neighbors share some Western concerns about the rise of China. However, having lived with China for thousands of years, they also know it would be futile to stop China. Instead, each of the neighbors, including major and middle powers like India and Japan, South Korea and Vietnam, will make pragmatic adjustments: pushing back against China when necessary, cooperating when it is mutually beneficial.

As the twenty-first century progresses steadily toward a multicivilizational world, the West could well learn a lesson or two from supple Asian minds. Instead of seeing the world in black and white terms, where binary choices are made between trust and distrust, the West could learn to live with successful non-Western societies, which were both similar and different from Western societies. They will share some key Western attitudes and retain their unique civilizational identities in other dimensions. This may well be the biggest test for Western societies in the realm of trust: can they "trust" societies that will never be fully Western in their identity?

\footnotetext{
Open Access This chapter is licensed under the terms of the Creative Commons AttributionNonCommercial-NoDerivatives 4.0 International License (http://creativecommons.org/licenses/bync-nd/4.0/), which permits any noncommercial use, sharing, distribution and reproduction in any medium or format, as long as you give appropriate credit to the original author(s) and the source, provide a link to the Creative Commons license and indicate if you modified the licensed material. You do not have permission under this license to share adapted material derived from this chapter or parts of it.

The images or other third party material in this chapter are included in the chapter's Creative Commons license, unless indicated otherwise in a credit line to the material. If material is not included in the chapter's Creative Commons license and your intended use is not permitted by statutory regulation or exceeds the permitted use, you will need to obtain permission directly from the copyright holder.
}

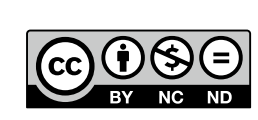

